\title{
PENDEKATAN KOMPETISI PEMBENTUKAN MASALAH DAN PEMBAHASAN SECARA ESTAFET BERKELOMPOK (PKPMSEB) UNTUK MENINGKATKAN AKTIVITAS DAN HASIL BELAJAR MAHASISWA
}

\author{
Armen \\ Staf Pengajar Biologi FMIPA Universitas Negeri Padang. \\ Korespondensi: J1. Prof. Dr. Hamka Air Tawar Padang, E-mail: urfan_baek@rocketmail.com.
}

\begin{abstract}
This research aimed at figuring out the effect of PKMSEB method toward learning achievement and involvement of Biology Department students in Research Methodology subject. This research employed a classroom action research. The population of the research was 70 students who were taking Research Methodology subject. The data were analyzed by means of descriptive statistics. The findings showed that PKMSEB method improved students' learning achievement although it was not high. Students' learning involvement was fairly high. In general, all elements of involvement activity and learning achievement improved, however, the percentage and the score of such improvement were not significant. Scientifically, such improvement can be accepted and the bypothesis was supported.
\end{abstract}

Kata kunci: aktivitas, hasil belajar, kompetisi pembentukan masalah, estafet berkelompok

\section{PENDAHULUAN}

$\mathrm{M}$ etodologi penelitian yang seharusnya lebih menarik minat mahasiswa untuk belajar, ternyata tidak sesuai dengan harapan, keterlibatan serta tanggung jawab moral mahasiswa terhadap kegiatan pembelajaran yang berlangsung sangat rendah. Penelitian ini mencoba mengusulkan alternatif formula pembelajaran yang diharapkan dapat mengatasi masalah belajar mahasiswa sebagai yang telah dijelaskan. Sesungguhnya fenomena sikap dan perilaku belajar mahasiswa merupakan indikasi atas lemahnya motivasi belajar yang dimiliki mahasiswa. Keadaan ini merupakan masalah klasik pengajaran yang dapat dijumpai di semua jurusan dahulu hingga sekarang. Fenomena ini tidak hanya dijumpai pada kegiatan belajar metodologi penelitian akan tetapi telah merupakan sikap dan perilaku belajar mahasiswa secara umum pada setiap kegiatan belajar, khususnya di Jurusan Biologi FMIPA. Oleh karena itu, keadaan ini perlu disikapi dan segera diantisipasi, karena selain rnenyangkut dengan kepentingan mahasiswa beserta masyarakat sebagai konsumen pendidikan, juga menyangkut akuntabilitas jurusan sebagai pengelola pembelajaran dimata publik. Keadaan ini akhirnya akan berpengaruh terhadap lemahnya antisipasi masyarakat dalam penyelenggaraan pendidikan.

Diskusi peneliti dengan teman kolaborasi menduga bahwa munculnya perilaku belajar mahasiswa sebagaimana dikemukakan disebabkan oleh metode mengajar dapat membangkitkan minat dan perhatian peserta didik terhadap pengajaran, minat dan perhatian memu- 
satkan landasan bagi hasrat belajar sehingga proses belajar mengajar berjalan dengan baik. Seorang pengajar (dosen) harus mampu menggunakan metode mengajar yang tepat, sehingga proses belajar mengajar lancar dan menyenangkan.

Menurut Muhammad Amin (1987: 98-99) seorang pengajar harus mampu memilih dan menetapkan metode mengajar yang efektif. Metode mengajar merupakan suatu cara yang digunakan pengajar dalam mengajarkan bahan pengajaran dengan memusatkan pada proses atau situasi belajar untuk mencapai tujuan pengajaran.

Diskusi dapat dilaksanakan dalam bentuk kelompok besar atau kelompok kecil, tergantung pada kemampuan mengelola, memimpin, dan mempertimbangkan tujuan yang ingin dicapai, Abdurrahman (1982: 1) menyatakan diskusi adalah pertukaran pikiran (gagasan, pendapat) antara dua orang atau lebih secara lisan, biasanya untuk mencari kesamaan pikiran.

Menurut Rastiyah, N.K. dan Yumiati Suharto (1985: 7), tujuan penggunaan metode diskusi adalah (1) dengan diskusi peserta didik didorong menggunakan pengetahuan dan pengalaman untuk memecahkan masalah, tanpa selalu berdantung pada pendapat orang lain. Mungkin diantara mahasiswa ada perbedaan segi pandang, sehingga memberikan jawaban yang berbeda. Hal ini tidak menjadi soal. Asal pendapat mahasiswa logis dan mendekati kebenaran. Jadi, peserta didik dilatih berpikir dan memecahkan masalah sendiri; (2) peserta didik mampu menyatakan pendapat secara lisan, karena hal itu perlu untuk melatih sifat dan sikap demokratis. Dengan demikian peserta didik melatih diri menyatakan pendapat sendiri secara lisan suatu masalah; (3) diskusi memberikan kemungkinan kepada peserta didik untuk belajar berpartisipasi dalam pembicaraan untuk memecahkan suatu masalah.

Metode diskusi akan baik dilaksanakan apabila mempersoalkan hal yang menarik minat dan perhatian mahasiswa, mengandung banyak kemungkinan jawaban, dapat merangsang pertimbangan, berpikir logis dan usaha membandingkan masalah. Metode diskusi mempunyai kelebihan. Kelebihan metode diskusi dapat disimak pendapat Statom yang dinyatakan Tahalele (1978, hal. 110), diskusi pendapat memberikan dorongan bagi setiap anggota kelompok untuk berbuat secara konstruktif, berfikir kreatif, dan mengembangkan pengalaman serta keahlian yang sangat bermanfaat bagi anggota lain". Sesuai dengan pendapat Statom tentang kebebasan metode diskusi Jos Daniel Parera (1988, hal 183) menyatakan metope diskusi merupakan (1) dilaksanakan sikap demokrasi; (2) pengujian sikap teloransi; (3) pengembangan kebebasan pribadi; (4) pengembangan latihan berpikir; (5) penambahan pengetahuan dan (6) kesempatan pengejawantahan sikap.

Menurut Raka Joni (1984: 1) kerja kelompok merupakan strategi belajar mengajar yang memiliki kadar cara belajar aktif dan produktif produktifitas tinggi, karena setiap anggota memiliki rasa kebersamaan yang dilandasi oleh satu tujuan". Karena "belajar dengan kelompok memungkinkan mahasiswa dapat belajar lebih efektif (Herman Hudojo, 1997: 313). Dalam kerja kelompok dengan "adanya tutor sebaya keterlibatan belajar mahasiswa menjadi lebih optimal, pembelajaran menjadi lebih terbuka dan demokratis karena antara sesama mahasiswa tidak ada hambatan psikologi sebagaimana mereka dengan dosen (Sriyanto, 2002: 3 7).

Kegiatan pembentukan masalah beserta pembahasan ini akan dapat membuat mahasiswa terlibat aktif secara fisik dan emosional selama kegiatan pembelajaran berlangsung. Proses pem- 
belajaran akan menyalut kekuatan mental dan psikologis mahasiswa untuk berpikir dalam memecahkan masalah. Menurut Dave Meier (2002: 33), orang akan dapat belajar lebih baik jika mereka terlibat secara aktif mengambil tanggung jawab penuh atas usaha belajar, sebab hal ini akan membantu membangkitkan minat dan tercipta makna pembahasan, dan nilai yang membangkitkan pada diri mahasiswa tentang belajar.

Kemudian kegiatan presentasi yang dilakukan secara estafet oleh beberapa orang presenter yang ditunjuk secara acak, selain dapat mendorong mahasiswa mempersiapkan diri menguasai materi pelajaran dengan baik, juga akan memaksa mahasiswa untuk senantiasa memusatkan perhatian kepada kegiatan pembelajaran yang berlangsung. Hal ini akan membuat keterlibatan mahasiswa dalam belajar semakin optimal. Disamping itu dalam kompetisi, ada hadiah dan hukuman, selain membuat suasana belajar hangat dengan luapan kegembiraan. Menurut Bobbi De Porter (1999: 38), "keberhasilan dalam berkompetisi ini dapat memberikan sugesti internal yang positif terhadap individu dalam kelompok, sugesti positif ini akan menumbuhkan emosional positif yang dapat membuat kemampuan kerja otak untuk berfikir menjadi lebih efektif Pendapat ini sejalan dengan apa yang dikemukakan Dave Meier (2002: 36), kegiatan presentase menyebabkan mahasiswa bangkit berdiri dari tempat duduk dan aktif secara pisik, dapat merangsang hubungan pikiran dan tubuh, selanjutnya akan memupuk motivasi belajar, sikap kristis dalam mengajukan pertanyaan, memberikan tanggapan, dan mengambil keputusan.

Strategi pembelajaran dosen yang cenderung tekstual dan monoton yang lebih terkesan seperti doktrin yang tak perlu dipertanyakan, membuat suasana belajar menjadi kaku dan tidak memberikan keluwesan dimana mahasiswa dapat berekreasi dan berimprovisasi secara bebas, strategi pembelajaran yang digunakan itu tidak mampu membangkitkan motivasi internal yang dapat mendorong mahasiswa untuk belajar secara optimal, akibatnya motivasi belajar mahasiswa lemah dan tanggung jawab mahasiswa terhadap kegiatan pembelajaran yang berlangsug menjadi rendah.

Dalam pendekatan PKPMSEB, mahasiswa tidak hanya sekadar berlatih membahas masalah atau soal yang sudah ada, akan tetapi mereka justru berlomba menemukan dan merumuskan sendiri masalah beserta solusi. Kemudian pada diskusi kelompok selama ini biasanya pembahasan masalah hanya di presentasikan oleh satu orang utusan kelompok dan pertanyaan oleh presenter dan anggota kelompok yang sudah disiapkan, tetapi pada pendekatan PKPMSEB hasil pembahasan masalah dipresentasikan oleh beberapa atau semua anggota kelompok secara estafet di depan kelas dan menjawab pertanyaan yang muncul dilakukan oleh orang-orang yang ditunjuk oleh anggota kelompok lain.

Dalam pendekatan PKPMSEB, pembelajaran mahasiswa dikelola melalui kegiatan kompetisi antar kelompok, setiap kelompok diwajibkan menyusun sejumlah soal atau masalah beserta pembahasan sesuai materi pembelajaran yang dipelajari. Selanjutnya masalah atau soal yang dibuat oleh masingmasing kelompok tersebut ditawarkan kepada kelompok lain untuk dibahas. Dalam kompetisi setiap kelompok diwajibkan membahas semua masalah yang dibuat dan ditawarkan oleh kelompok lain. Kelompok yang berhasil akan mendapat penambahan nilai atau poin, sebaliknya kelompok yang gagal akan mendapat pengurangan nilai.

Berdasarkan permasalahan penelitian, maka dikemukakan tujuan penelitian (1) Untuk mengetahui peningkatan hasil belajar mahasiswa setelah penggunaan metode Pembelajaran Pendekat- 
an Pembentukan Masalah dan Pembahasan Secara Estapet kelompok (PKPM) (2) untuk mengetahui peningkatan keterlibatan mahasiswa dalam dengan penggunaan metode Pembelajaran Pendekatan Pembentukan Masalah dan Pembahasan Secara Estapet Berkelompok (PKPM).

\section{METODE PENELITIAN}

\section{Jenis Penelitian}

Jenis penelitian ini adalah penelitian tindakan kelas, penelitian ini dilaksanakan di kelas dalam pembelajaran mata kuliah Metode Penelitian, Pembelajaran ini dimaksudkan untuk meningkatkan keterlibatan mahasiswa dalam pembelajaran dan meningkatkan hasil belajar mahasiswa.

\section{Populasi dan Sampel}

Populasi penelitian berjumlah 70 orang yang terkelompok dalam 2 lokal, yang mengambil mata kuliah metodologi penelitian di Jurusan Biologi FMIPA UNP. Penentuan lokal sampel dilakukan atas dasar total sampling dengan tetap mengutamakan prinsip representatif dari objek penelitian.

Di jurusan Biologi FMIPA untuk tahun ajaran 2005 terdapat dua lokal mahasiswa yang mengambil mata kuliah Metodologi Penelitian dengan karakteristik mahasiswa relatif sama. Hal ini terlihat dari segi motivasi, cita-cita, pola dan kebiasaan belajar, serta latar belakang lingkungan sosial budaya mahasiswa yang tidak jauh berbeda. Demikian juga kondisi pisik Jurusan Biologi FMIPA Biologi serta persoalan-persoalan keterbatasan alat dan sarana belajar, kekurangan tenaga pengajar secara kuantitas dan kualitas, dukungan masyarakat dan orang tua mahasiswa yang kurang memadai dan lain-lain, merupakah masalah urgensi yang mewarnai hampir semua mahasiswa Jurusan bio- logi FMIPA UNP.

\section{Rencana Tindakan}

Kegiatan pembelajaran pada penelitian ini diiaksanakan selama tiga siklus, setiap siklus terdiri dari tahapan kegiatan yang meliputi perencanaan (planning), implernentasi tindakan (acting), pengamatan (observing) dan refleksi (reflecting).

\section{Perencanaan}

Tahap perencanaan meliputi kegiatan penyusunan skenario tindakan pembelajaran, mempersiapkan instrument, dan personal yang diperlukan dalam pelaksanaan kegiatan penelitian.

Sesuai dengan judul penelitian ini : kompetisi pembentukan masalah dan pembahasan secara estafet berkelompok, maka pembelajaran mahasiswa dikelola melalui kegiatan perlombaan (kompetisi) merumuskan masalah beserta pembahasan secara berkelompok. Secara umum kegiatan pelajaran pada setiap siklus dapat disketsakan:

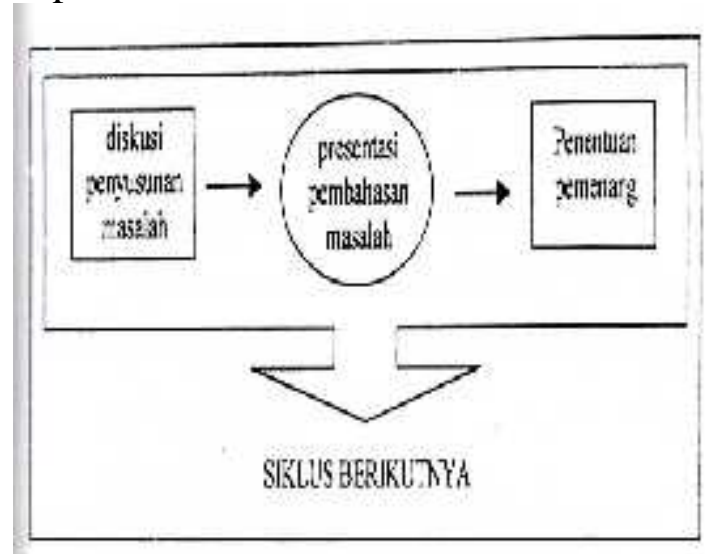

Setiap kelompok diminta menyusun sejumlah soal atau masalah beserta pembahasan sesuai materi Penawaran yang dipelajari, selanjutnya masalah atau soal yang dirumuskan ditawarkan untuk dibahas kepada kelompok lain. Kelompok yang tidak berhasil merumuskan masalah atau soal dalam batas waktu yang ditentukan akan mendapat sangsi berupa pengurangan nilai kelompok atau tidak diizinkan mengikuti kegiatan se- 
lanjutnya. Penawaran masalah hanya diperbolehkan apabila semua anggota dalam kelompok betul-betul telah menguasai pembahasan masalah yang mereka buat dengan baik. Kelompok yang melanggar aturan diberi sangsi berupa pengurangan nilai atau point kelompok.

Selanjutnya setiap kelompok diminta membahas semua masalah yang dibuat oleh kelompok lain. Kelompok yang telah siap dapat menawarkan diri untuk tampil lebih awal. Pembahasan masalah atau soal disajikan melalui kegiatan presentasi secara estafet (bersambung) di depan kelas oleh satu atau dua orang presenter suatu kelompok. Presenter ini ditunjuk secara acak oleh dosen atau mahasiswa dari kelompok lain. Jika presenter suatu kelompok gagal menyajikan pembahasan masalah atau soal yang dikerjakan, maka kesempatan diberikan kepada kelompok lain secara rebutan. Kolompok yang berhasil akan mendapat hadiah berupa penambahan nilai, dan sebaliknya kelompok yang gagal akan mendapat hukuman berupa pengurangan nilai. Akhirnya setelah kegiatan presentasi oleh semua kelompok selesai dilaksanakan, maka kelompok yang mendapat nilai tertinggi dikukuhkan sebagai juara dan kepada kelompok diberikan penghargaan berupa prediket kolompok super jenius, kelompok jenius, kelompok pintar, dan kelompok normal.

Sistim penilaian pada penilaian ini dilakukan terhadap dua hal yaitu penilaian proses dan penilaian hasil. Penilaian proses menekankan pada keterlibatan mahasiswa dalam proses pembelajaran, sedangkan penilaian hasil diperoroleh melalui tes hasil belajar, Jadi nilai akhir hasil belajar seorang mahasiswa merupakan gabungan dari nilai partisipasi dalam mengikuti kegiatan pembelajaran dan nilai yang diperoleh melalui tes hasil belajar.

Di awal kegiatan belajar setiap kelompok diberi sejumlah nilai dasar yang sama besar, nilai dasar tiap ke- lompok ini dapat berkurang atau bertambah sebagaimana yang telah dijelaskan tadi. Point atau nilai dasar ini digunakan untuk penambah nilai yang diperoleh mahasiswa melalui tes hasil belajar yang dilaksanakan di akhir siklus belajar.

Selama kegiatan pembelajaran berlangsung semua aturan main dalam kegiatan pembelajaran seperti presentasi secara estafet, penunjukkan presenter secara acak, dan pemberian hadiah serta hukuman sebagaimana diuraikan bertujuan agar kegiatan pembelajaran mahasiswa dapat berlangsung dengan efektif untuk mencapai tujuan yang diharapkan.

Kegiatan penelitian ini dikelola oleh tim kerja dengan jumlah personel sebanyak tiga orang yang direkrut dari dosen mata pelajaran yang sesuai. Tiap personel memiliki tugas dan tanggung jawab masing-masing. Kegiatan penelitian dimulai dari penyiapan instrument yang meliputi penyusunan sarana pendukung kegiatan pembelajaran seperti rencana pembelajaran setiap siklus, media pembelajaran, papan kode peserta, matrik pengamatan aktifitas belajar mahasiswa, dan matrik pengamatan aktifitas pengelolaan pembelajaran oleh dosen, dan nilai evaluasi berupa perangkat tes.

\section{Implementasi Tindakan}

Pada pelaksanaan tindakan pembelajaran ada beberapa aktifitas yang dilakukan oleh dosen atau mahasiswa, aktifitas dosen meliputi kegiatan berikut ini:

a. Menginformasikan materi kuliah yang akan dipelajari mahasiswa dan menuliskannya di papan tulis, serta menginformasikan tujuan pembelajaran sehubungan dengan kompetensi yang harus dimiliki mahasiswa setelah mereka mengikuti kegiatan pembelajaran.

b. Menginformasikan kepada mahasiswa tentang strategi pembelajaran yang digunakan, meliputi tata tertib yang 
harus ditaati mahasiswa, serta kegiatan-kegiatan kelompok yang harus diikuti mahasiswa selama kegiatan pembelajaran berlangsung, misal mencari informasi tentang materi pelajaran dari buku sumber, menyusun dan membahas soal-soal, melaksanakan presentasi, dan membuat simpulan tentang materi kuliah yang telah dipelajari.

c. Membagi mahasiswa atas beberapa kelompok. Tiap kelompok terdiri dari 5 atau 6 orang anggota, lalu meminta mahasiswa untuk duduk menurut kelompok masing-masing dan memasang nomor kode yang telah diberikan pada dada kiri.

d. Dosen memulai kegiatan pembelajaran pembukaan dengan terlebih dahulu welakukan apersepsi, sugesti, dan motivasi. perbaikan untuk diimplementasikan pada siklus kegiatan pembelajaran berikut.

\section{Kegiatan Mahasiswa dalam Pendekat- an PKPMSEB}

1. Memahami dan mentaati tata tertib dan aturan dari strategi pembelajaran yang digunakan dosen.

2. Mengetahui dan memahami dengan baik tujuan pembelajaran sehubungan dengan kompetensi yang harus dimiliki setelah mengikuti kegiatan pembelajaran.

3. Duduk berkelompok dan memasang nomor kokarde yang diberikan.

4. Menggali informasi dari buku sumber tentang materi kuliah yang hendak dipelajari bersama teman dalam kelompok.

5. Merumuskan masalah atau soal-soal beserta pembahasan bersama teman dalam kelompok.

6. Menawarkan masalah atau soal-soal yang telah dibahas dengan cara menaruhnya di tempat yang telah disediakan Dosen di depan kelas.

7. Mengambil dan membahas masalah atau soal-soal yang dibuat oleh ke- lompok lain bersama teman dalam kelompok.

8. Mempresentasikan semua pembahasan masalah atau soal-soal yang telah dikerjakan bersama dengan beberapa orang teman kelompok secara bersambung (estafet) di depan kelas.

9. Mengkritisi soal-soal atau memperbaiki jawaban yang dikerjakan oleh kelompok lain jika perlu.

10. Membuat simpulan materi pelajaran yang telah dipelajari dan melampirkan nama semua anggota kelompok.

\section{Rencana Pengamatan}

Kegiatan observasi bertujuan mencatat dan mengumpulkan semua data dan informasi tentang peristiwa yang terjadi pada kelas penelitian, ada tiga macam data dan informasi yang dikumpul pada penelitian ini yaitu data aktifitas dan perilaku belajar mahasiswa, data aktifitas pengelolaan pembelajaran oleh dosen, dan data prestasi hasil belajar mahasiswa

Data aktifitas belajar mahasiswa dan aktifitas pengelolaan pembelajaran oleh dosen dicatat melaui pengamatan sejawat oleh dua orang teman kolaborasi. Demikian juga aktifitas belajar mahasiswa selain melalui pengamatan sejawat juga dilakukan oleh peneliti sendiri, Pengamatan dilakukan secara langsung ketika kegiatan pembelajaran berlangsung di kelas, menggunakan instrumen yang telah dipersiapkan. Data prestasi hasil belajar mahasiswa diperoleh melalui kegiatan evaluasi menggunakan perangkat tes yang dilaksanakan setelah siklus pembelajaran berakhir.

\section{Analisis dan Refleksi}

Penelitian ini bertujuan menemukan suatu model atau prototype tertentu untuk kegunaan tertentu, dalam hal ini adalah menentukan pengaruh tindakan (action) pembelajaran yang digunakan dalam penelitian terhadap prestasi hasil belajar mahasiswa kelas sampel, oleh karena itu, proses dan hasil tindakan 
penelitian perlu dievaluasi.

Kegiatan evaluasi dilakukan secara kolaboratif menggunakan data dan informasi yang terkumpul selama kegiatan penelitian. Data tersebut berupa nilai tes hasil belajar mahasiswa dan data yang berhubungan dengan proses dan pelaksanaan kegiatan penelitian.

Semua data yang ada dikaji dan ditelaah, kemudian hasil yang diperoleh dibandingkan dan diberikan penafsiran, apakah perlakuan pembelajaran yang dilaksanakan pada penelitian telah sesuai dengan rencana tindakan dan telah menunjukan hasil yang mengarah pada pencapaian tujuan, atau apakah prestasi hasil belajar yang diperoleh mahasiswa signifikan dengan perlakuan pembelajaran yang diberikan selama penelitian, atau apakah hasil yang dicapai mahasiswa tersebut telah memenuhi tujuan yang diharapkan, jika belum dimana letak keksalahan dan kekurangan. Hasil analisis digunakan sebagai pedoman dan acuan untuk rencana tindakkan perbaikan yang akan diimplementasikan pada kegiatan pembelajaran siklus II dan siklus III.

\section{Pergantian siklus}

Pergantian siklus dilakukan berdasarkan tingkat keberhasilan yang dicapai. Tingkat keberhasilan yang dicapai meliputi (a) ketuntasan membuat pertanyaan dan masalah; (b) kemampuan menjawab pertanyaan dan pembahasan; (c) kemampuan menyajikan materi ajar; (d) tingkat keterlibatan mahasiswa dalam diskusi dan (e) Hasil belajar mahasiswa matakuliah metodologi penelitian

Perbaikan pembelajaran setiap siklus dilakukan berdasarkan permasalahan dan hambatan yang ditemui pada siklus sebelumnya

\section{Teknik pengumpulan Data}

Teknik pengumpulan data penelitian dengan menggunakan lembaran observasi dan tes yang disusun sesuai dengan tujuan penelitian, yang diobservasi dalam pembelajaran adalah (1) aktifitas menggali referensi; (2) aktifitas diskusi; (3) aktifitas mengkritisi; (3) membahas masalah kelompok sendiri; (4) membahas masalah kelompok lain; (5) kerja sama dalam kelompok; (6) kemampuan berkomunikasi; (7) menghargai pendapat teman; (8) komitmen dan tanggung jawab.

Data observasi pembelajaran dihitung menggunakan rumus persentase yang dikemukakan Suharsimi Arikunto (1989, Hal. 214).

Nilai $=$

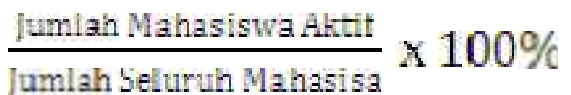

$$
\begin{aligned}
\text { Kriteria : } 81-100 \% \text { sangat Baik } \\
61-81 \% \text { baik } \\
21-60 \% \text { cukup } \\
21-40 \% \text { kurang } \\
0-20 \% \text { sangat kurang }
\end{aligned}
$$

Data hasil belajar diperoleh dari:

1. Setiap mahasiswa diberi nilai dasar sebesar 20. Nilai dasar ini akan bertambah atau berkurang salama pembelajaran. Mahasiswa yang mampu menjawab masalah yang diajukan akan menadapat tambahan nilai dan yang tidak mampu menjawab akan menadapat pengurangan nilai.

2. Kisaran nilai setiap siklus 5-25. Total nilai terendah untuk ketiga siklus 25 dan paling tinggi 75 .

3. Nilai akhir mahasiswa dalam matakuliah Metodologi Penelitian: 25-75.

\section{HASIL DAN PEMBAHASAN}

\section{Hasil Belajar Mahasiswa}

Secara umum Hasil belajar mahasiswa mengalami peningkatan dari siklus I sampai siklus III. Peningkatan hasil belajar tidak tinggi namun secara ilmiah dapat diterima bahwa pembelajaran 
menggunakan Pendekatan Kompetisi Pembentukan Masalah dan Pembahasan Secara Estafet Berkelompok bisa meningkatkan hasil belajar. Peningkatan Hasil belajar 59,73 menjadi 63,44 dan 63,44 menjadi 66,57 dapat dijadikan dasar bahwa pendekatan pembelajaran yang dilakukan mempengaruhi mahasiswa meningkatkan hasil belajar. Jika disimak lebih dalam pengkatan hasil belajar yang diperoleh mahasiswa sangat terkait dengan tingkat keterlibatan mahasiswa dalam pembelajaran.

\section{Keterlibatan Mahasiswa dalam Pro- ses Pembelajaran}

Besaran keterlibatan mahasiswa dalam pembelajaran dinyatakan secara kualitatif, yaitu dengan kategori sangat baik, baik, cukup dan kurang. Secara umum tingkat keterlibatan mahasiswa dalam pembelajaran menggunakan PKPMSEB tergolong baik karena hasil dari 3 siklus pembelajaran (12 kali pertemuan), persentase keterlibatan mahasiswa memperoleh nilai sangat baik $(3,9 \%)$, baik $(41,33 \%)$, cukup $(51,71 \%)$ dan nilai kurang $(1,23 \%)$. Jika disimak masing-masing siklus, keterlibatan mahasiswa meningkat dari cukup menjadi baik.

Untuk lebih rinci bagaimana kondisi keterlibatan mahasiswa dalam pembelajaran PKPMSEB, dapat dijelaskan masing-masing aktifitas:

a. Siklus I

1. Menggali Referensi, keterlibatan mahasiswa menggali referensi mendapat kategori baik, sekitar $52 \%$ mahasiswa mendapat nilai baik. Keadaan ini menunjukkan bahwa mahasiswa sudah terlatih belajar menggali referensi. Mahasiswa sudah terbiasa berdiskusi. PKPMSED telah memberi peluang bagi mahasiswa untuk menggali referensi lebih giat.

2. Berdiskusi, keterlibatan mahasiswa berdiskusi termasuk kategori baik.
Sekitar 9,50\% termasuk kategori sangat baik, $61,97 \%$ memperoleh kategori baik. Keadaan ini menunjukkan bahwa mahasiswa sudah aktif terlibat berdiskusi. Keterlibatan mahasiswa berdikusi, disebabkan oleh kecenderungan pembelajaran di Jurusan Biologi menggunakan metode diskusi sehingga mahasiswa terbiasa melakukan diskusi.

3. Mengkritisi, keterlibatan mahasiswa mengkritisi termasuk kategori baik, sekitar 49,45\% mahasiswa memperoleh nilai kategori baik dan 2,54\% memperoleh nilai kategori sangat baik. Keadaan ini menunjukkan bahwa mahasiswa sudah aktif mengkritisi permasalahan yang berkembang dalam pembelajaran. Keterlibatan mahasiswa mengkritisi dalam pembelajaran sangat berkaitan dengan kepekaan dan wawasan mahasiswa yang sudah terbiasa mengkritisi permasalahan yang muncul.

4. Membahas Masalah Kelompok Sendiri, keterlibatan mahasiswa membahas masalah kelompok sendiri termasuk kategori cukup. Keterlibatan mahasiswa memperoleh nilai cukup sekitar $73,82 \%$. Keadaan ini menunjukkan keterlibatan mahasiswa membahas masalah kelompok sendiri tidak menonjol. Kenyataan ini barang kali disebabkan mahasiswa lebih berkonsentrasi pada aktifitas menggali referensi, mengkritisi dalam berdiskusi.

5. Membahasa Masalah Kelompok Lain, keterlibatan mahasiswa membahas masalah kelompok lain tergolong cukup (70,42\%). Keadaan ini menunjukkan bahwa keterlibatan mahasiswa tidak menonjol, faktor penyebab tidak menonjol aktifitas mahasiswa, mungkin mahasiswa lebih berkonsentrasi dan menggali referensi, diskusi dan mengkritisi. 
6. Kerja Sama Dalam Kelompok, keterlibatan mahasiswa dalam kerja sama kelompok tergolong cukup $(71,65 \%)$. Keadaaan ini menunjukkan mahasiswa lebih cenderung bekerja sendiri, penyebab mahasiswa cenderung bekerja sendiri sangat terkait dengan keinginan tampil sendiri (mengaktualisasikan diri).

7. Kemampuan Berkomunikasi, keterlibatan mahasiswa termasuk kategori baik $(46,05 \%)$ dan kategori cukup 52\%, indikasi ini menunjukkan bahwa kemampuan berkomunikasi mahasiswa cukup baik. Penyebab cukup baik kemampuan berkomunikasi mahasiswa adalah sering terlibat dalam diskusi, mempunyai wawasan dan ingin tampil menunjukkan kemampuan individu.

8. Menghargai Pendapat Teman, keterlibatan mahasiswa cukup $(76,11$ $\%)$. Keterlibatan mahasiswa tidak menonjol, keadaan ini disebabkan mahasiswa lebih cenderung memperlihatkan kemampuan individu dan mementingkan diri sendiri.

9. Komitmen dan Tanggungjawab, keterlibatan mahasiswa termasuk kategori cukup (81,39\%), keterlibatan mahasiswa tidak menonjol faktor penyebab, kemungkinan mahasiswa menganggap bahwa komitmen dan tanggungjawab tidak penting dilakukan. Keterkaitan kategori cukup mahasiswa dalam diskusi memberi petunjuk bahwa komitmen dan tanggungjawab mahasiswa memerlukan pengarahan dan bimbingan.

Keterlibatan mahasiswa secara umum dalam pembelajaran pada siklus I sudah cukup baik. Persentase keterlibatan mahasiswa menunjukkan kategori baik $(36,98 \%)$ dan sangat baik $(2,4)$ dan kategori cukup baik $(57,78 \%)$. Elemen aktivitas keterlibatan mahasiswa yang masih tergolong cukup adalah Pembahasan Masalah Kelompok Sendiri, membahas Masalah Kelompok Lain, Kerjasama Dalam Kelompok, Komitmen dan Tanggungjawab. Keadaan ini lebih cenderung disebabkan mahasiswa konsentrasi pada elemen kegiatan lain yang lebih menampakkan kemampuan individu.

\section{b. Siklus II}

Mengingat elemen kegiatan membahas kelompok Sendiri, membahas masalah kelompok lain, kerjasama dalam kelompok, menghargai pendapat teman dan komitmen serta bertanggung jawab masih tergolong baik (tidak terialu buruk) maka pada siklus II hanya dilakukan sedikit perbaikan pembelajaran. Menyimak keterlibatan mahasiswa cukup baik, dan hanya pada elemen aktifitas tertentu mahasiswa masuk kategori cukup, maka perbaikan pembelajaran dilakukan hanya sekadar mendorong keterlibatan mahasiswa dalam elemen kegiatan: Membahas Kelompok Sendiri, Membahas Kelompok Lain, Menghargai Pendapat Teman dan Komitemen serta Tanggungjawab.

Pada siklus II dilakukan perbaikan agar terjadi peningkatan hasil belajar dan keterlibatan mahasiswa dalam pembelajaran. Permasalahan yang tampak bagaimana mendorong perubahan sikap kurang berpartisipasi membahas permasalahan, menghargai pendapat teman, dan tanggungjawab. Pada siklus II, Dosen pembina mata kuliah memberikan pengarahan dan dorongan agar mahasiswa aktif membahas masalah kelompok, menghargai pendapat teman dan mau bekerjasama dan bertanggung jawab. Pengarahan ini tidak dilakukan pada siklus I.

Keterlibatan mahasiswa dalam pembelajaran pada siklus II masuk kategori baik. Persentase keterlibatan mahasiswa memperoleh nilai kategori baik $(41,25 \%)$ sangat baik $(3,36 \%)$ dan nilai cukup $(40,22 \%)$. Secara umum terjadi peningkatan persentase peningkatan 
keterlibatan mahasiswa.

Persentase peningkatan keterlibatan mahasiswa dalam pembelajaran dari siklus I ke siklus II: kategori sangat baik $1,13 \%$, baik $4,27 \%$ dan kategori cukup berkurang $8,56 \%$.

Peningkatan keterlibatan mahasiswa dalam pembelajaran terjadi pada elemen-elemen aktifitas: Aktifitas Menggali Referensi, Aktifitas Berdiskusi, Aktifitas Mengkritisi, Membahas Masalah Kelompok Sendiri, Kerjasama dalam kelompok, Kemampuan Berdiskusi, Menghargai Pendapat Teman dan Komitemen tanggung jawab.

Menyimak elemen aktifitas pada siklus I mendapat nitai kategori cukup mengalami perubahan. Persentase perolehan nilai kategori (cukup) berkurang dan nilai kategori (baik) naik:

1. Membahas Masalah Kelompok Sendiri pada siklus I, keterlibatan mahasiswa kattegori baik $(36,32 \%)$ naik menjadi $37,14 \%$, kategori cukup $(73,82 \%)$ turun menjadi $64,13 \%$.

2. Membahas Masalah Kelompok Lain pada siklus I, keterlibatan mahasiswa kategori baik $(27,39 \%)$ naik menjadi $(28,26 \%)$ kategori cukup $70,43 \%$ turun menjadi $71,73 \%$.

3. Kerja Sama Dalam Kelompok pada siklus 1, keterlibatan mahasiswa kategori baik $(26,77 \%)$ naik menjadi $32 \%$ dan kategori cukup $(71,65 \%)$ turun menjadi $(67,27 \%)$.

4. Menghargai Pendapat Teman pada siklus 1, keterlibatan mahasiswa kategori baik (20\%) naik menjadi $25,55 \%$ dan kategori cukup $(76,44 \%)$ turun menjadi $(76,11 \%)$.

5. Komitmen dan tanggung jawab pada siklus I, keterlibatan mahasiswa kategori baik $(12,01 \%)$ naik menjadi $(14$, $54 \%)$ dan kategori cukup $(81,39 \%)$ turun menjadi $(31,27 \%)$.

Peningkatan keterlibatan mahasiswa hampir pada seluruh element aktifitas, terutama pada elemen-elemen aktifitas pada siklus I rendah menjadi naik.
Kenaikan persentase sangat dipengaruhi oleh perlakuan metode PKPMSEB yaitu memberikan pengarahan dan dorongan yang berhubungan dengan membahas persoalan kelompok, menghargai teman dan komitmen dalam diskusi. Peningkatan persentase keterlibatan mememang kecil tapi cukup berarti jika dikaitkan dengan perubakan sikap yang dimiliki mahasiswa dalam pembelajaran diskusi kelompok. melakukan perbaikan pada siklus II dapat meningkatkan persentase keterlibatan mahasiswa ke kategori lebih baik, maka pada siklus III tidak dilakukan perbaikan pembelajaran. Bentuk pembelajaran sama dengan siklus II.

\section{c. Siklus III}

Setelah dilakukan tindakan pada siklus III, dapat dijelaskan keterlibatan mahasiswa dalam pembelajaran menggunakan metode PKPMSEB:

1. Aktifitas Menggali Referensi: pada siklus II, keterlibatan mahasiswa kategori baik $(58,54 \%)$ naik menjadi $61,84 \%$.

2. Aktifitas berdiskusi pada siklus II, kategori baik $(65,31 \%)$ naik menjadi $63,79 \%$.

3. Aktifitas mengkritisi pada siklus II, kategori baik $(52,53 \%)$ naik menjadi $57.97 \%$.

4. Membanas Masalah Kelompok Sendiri pada siklus II, kategori baik $(35,14 \%)$ naik menjadl $40,64 \%$.

5. Membahas Masalah Kelompok Lain pada siklus II, kategori baik $(28,26 \%)$ naik menjadi $33,45 \%$.

6. Kerjasama Dalam Kelompok pada silus II, kategori baik (32\%), naik menjadi $33,45 \%$.

7. Kemampuan Berkomunikasi, pada siklus II, kategori baik $(61,45 \%)$, naik menjadi 62,31

8. Menghargai Pendapat Teman, pada siklus II, kategorl baik $(23,25 \%)$ naik menjadi $34,05 \%$.

9. Komitmen dan Tanggungjawab, pada siklus II, kategori baik (14,54\%), naik menjadi $24 \%$. 
Keterlibatan mahasiswa dalam pembelajaran pada siklus III meningkat. Secara umum elemen aktifitas keterlibatan mahasiswa meningkat kecuali elemen aktifitas berdiskusi turun 1,52\%. Penurunan keterlibatan mahasiswa elemen aktiftas berdiskusi disebabkan mahasiswa sudah merasa jenuh melaksanakan diskusi selama 3 siklus dan 12 kali pertemuan. Elemen aktifitas yang naik jelas sangat terkait dengan pengaruh metode pembeiajaran dan Perbaikan tindakan yang diberikan.

\section{PENUTUP}

\section{Kesimpulan}

Berdasarkan analisis data hasil dan pembahasan maka disimpulkan:

1. Hasil belajar matakuliah metodologi penelitian mahasiswa Biologi Tahun Ajaran 2004 meningkat menggunakan Pembelajaran Pendekatan Kompetisi Pembetukan Masalah dan Pembahasan Secara Estafet Berkelompok (PKM SEB). Besaran peningkatan hasil belajar bergeser tidak tinggi.

2. Keterlibatan mahasiswa dalam pembelajaran menggunakan Pendekatan Kompetisi Pembentukan Masalah dan Pembahasan Secara Estafet Berkelompok cukup tinggi.

3. Secara umum semua elemen aktifitas keterlibatan dan hasil belajar mahasiswa meningkat tetapi persentase dan

\section{DAFTAR RUJUKAN}

Amin, Moh. 1987. Pengajaran Ilmu Pengetahuan Alam dengan Menggunakan Metode Discovery dan Inquiry. Bagian I. Jakarta: Departemen Pendidikan dan Kebudayaan Direktorat Jenderal Pendidikan Tinggi P2LPTK.

Anonymus. 1985. Buku Pedoman Penulisan Soal EBTANAS Tahun angka peningkatan tidak besar. Secara ilmiah peningkatan dapat diterima dan hipotesis yang dirmuskan terbukti.

\section{Saran}

Memperhatikan hambatan dalam pelaksanaan penelitian tindakan Pendekatan Kompetisi Pembentukan Masalah dan Pembahasan Secara Berkelompok pada seta siklus, maka disarankan Jumlah kelompok diskusi, sebaiknya tidak lebih dari pada 6 kelompok. Perumusan dan penulisan masalah kelompok, sebaiknya dilakukan di luar waktu pembelajaran di kelas karena perumusan dan pembahasan masalah memakan banyak waktu sehingga mengurangi waktu presentase dan diskusi. Perencanaan dan penjadualan waktu dalam pembelajaran harus jelas dan pemanfaatan waktu harus disiplin. Penggunaan waktu yang tidak disiplin mengakibatkan pembahasan masalah tidak tuntas setiap pertemuan. Perbandingan jumlah observer dengan mahasiswa harus seimbang (1: 10). Jika tidak seimbang menyulitkan dalam pengamatan aktifitas mahasiswa. Pembelajaran menggunakan Pendekatan Kompetisi Pembentukan Masalah dan Pembahasan Secara Estafet Berkelompok harus dipimpin oleh seorang dosen yang mempunyai keterampilan memimpin diskusi. Jika dipimpin oleh dosen yang tidak terampil maka pelaksanaan pembelajaran kurang efektif.

Ajaran 1985/1986. Jakarta: Dirjendikdasmen.

Anonymus. 1999. Penelitian Tindakan. Jakarta: Departemen Pendidikan dan Kebudayaan. Direktorat Jenderal Pendidikan Dasar dan Menengah Umum.

Anonymus. 2000. Metode Alternatif Belajar Mengajar Ilmu Pengetahuan 
Alam. Jakarta: Departemen Pendidikan Nasional. Direktorat Jenderal Pendidikan Dasar dan Menegah Umum.

Anonymus. 2002. Pelangi Pendidikan. Jakarta: Departemen Pendidikan Nasional. Direktorat Jenderal Pendidikan Dasar dan Menegah Umum.

Anonymus. 2003. Pedoman Penyelenggaraan Program Percepatan Belajar SD, SMP dan SMA. Jakarta: Departemen Pendidikan Nasional. Direktorat Jenderal Pendidikan Dasar dan Menengah Umum.

Arikunto, Suharsimi. 1997. Prosedur Penelitian Suatu Pendekatan Praktek. Jakarta: Rineka Cipta.

Hudojo, Herman. 1997. Pengembangan Kurikulum Matematika. Surabaya: Usaha Nasional.
Joni, Raka. 1984. Kerja Kelompok. Jakarta: Proyek Pengembangan Lembaga Pendidikan Tenaga Pendidikan, Departemen Pendidikan

Meier, Dave. 2002. The Accelerated Learning. Bandung: Kaifa. Porter, De Bobbe. 1999. Quantum Learning. Bandung: Kaifa.

Roestiyah N.K. dan Yumiati Suharto. 1985. Strategi Belajar Mengajar. Jakarta: Bina Aksara.

Staton, F. Thomas. 1978. Cara Mengajar dengan Hasil yang Baik. Terjemahan J.F. Tahalele. Bandung: CV. Diponegoro.

Universitas Muhammadyah Yogyakarta 2002. Majalah Pendidikan Gerbang, Edisi 5 Th. II. Yogya-karta: Lembaga Penelitian dan Pengembangan (LPG). 